\title{
Pengaruh Plyometric Training Dalam Bentuk Circuit Training Terhadap Tinggi Lompatan Mahasiswa Pemain Bola Voli Pantai Prodi Penjas Universitas Bengkulu \\ The Influence of Plyometric Training in The Form of Circuit Training on the Leap Height of Beach Volleyball Players at Bengkulu University's Physical Education Program
}

\author{
Pernando Pevriansyah $^{1}$, Tono Sugihartono ${ }^{2}$, Arwin $^{3}$ \\ ${ }^{123}$ Pendidikan Jasmani, Universitas Bengkulu, Jl. WR Supratman Kandang Limun, Bengkulu, \\ 3871A, Indonesia
}

\begin{abstract}
Abstrak
Penelitian ini bertujuan untuk mengetahui pengaruh plyometric training dalam bentuk circuit training terhadap tinggi lompatan mahasiswa pemain bola voli pantai Prodi Penjas Universitas Bengkulu. Metode yang digunakan dalam penelitian ini adalah metode eksperimen, dengan memberikan perlakuan latihan plyometrics training pada sampel berjumlah 30 orang. Instrumen untuk mengukur tinggi lompatan adalah vertical jump pasir. Teknik analisis data pada penelitian ini menggunakan rumus uji-t, dengan tingkat signifikan $\mathrm{a}=0.05$. Hasil penelitian di peroleh $\mathrm{t}$ hitung $=9.00, \mathrm{t}$ tabel $=1.697$, ternyata bila dibandingkan nilai $\mathrm{t}$ hitung sebesar 9.00, > t table 1.697 dan dapat disimpulkan bahwa ada pengaruh yang signifikan latihan plyometric training dalam bentuk circuit training terhadap tinggi lompatan mahasiswa pemain voli pantai prodi Penjas Universitas Bengkulu, secara signifikan pada taraf $a=0.05$.
\end{abstract}

Kata kunci: Circuit Training, Plyometric, Voli Pantai

\begin{abstract}
This study aims to determine the effect of plyometric training in the form of circuit training on the jump height of beach volleyball students in the Physical Education Study Program, Bengkulu University. The method used in this study is an experimental method, by giving plyometrics training treatment to a sample of 30 people. The instrument for measuring jump height is the vertical jump sand. The data analysis technique in this study used the $t$-test formula, with a significant level of $=0.05$. The results of the study obtained t count $=9.00, t$ table $=1.697$, it turns out that when compared to the t-count value of 9.00, > t table 1.697 and it can be concluded that there is a significant effect of plyometric training in the form of circuit training on the jump height of beach volleyball students in the study program. Bengkulu University Physical Education, significantly at the level of $=0.05$.
\end{abstract}

Keywords: Beach Volleyball, Circuit Training, Plyometric 


\section{PENDAHULUAN}

Pendidikan adalah pembelajaran dimana disana ada pengetahuan, keterampilan, dan kebiasaan yang diturunkan dari satu generasi ke generasi selanjutnya melalui pengajaran, pelatihan, dan penelitian. Pendidikan di Negara Indonesia sekarang ini sedang mengalami masa-masa transisi dalam proses penerapan pembelajaran yang sebelumnya dilakukan secara langsung di dalam ruang kelas kini harus beralih ke dalam kegiatan pembelajaran jarak jauh atau daring.

Dalam pendidikan ada banyak aspek yang terdapat di dalamnya, antara lain: 1. Aspek kognitif, 2. Aspek afektif, dan 3. Aspek psikomotorik. Aspek kognitif adalah kemampuan yang mencakup kegiatan mental (intelektual). Aspek afektif adalah ranah yang berkaitan dengan sikap, moral dan nilai-nilai kehidupan. Sedangkan aspek psikomotorik merupakan ranah yang berkaitan dengan keterampilan (skill) biasanya berhubungan dengan aktifitas fisik seperti lari, melompat, melempar, menendang, dan menari.

Pendidikan merupakan usaha sadar yang dilakukan manusia untuk mengembangkan potensi manusia lain atau memindahkan nilai dan norma yang dimilikinya kepada orang lain dan masyarakat. Proses pemindahan nilai dan norma itu dapat dilakukan dengan berbagai cara diantaranya adalah pertama, melalui pengajaran kedua, melalui pelatihan ketiga, melalui indroktrinasi. Kalau dilihat pendapat diatas, maka belajar adalah suatu proses memanusiakan manusia, dimana hanya melalui belajar manusia dapat menemukan dirinya dalam relasinya dengan sesama, lingkungan dan penciptanya. Melalui belajar manusia mengaktualisasikan dirinya dengan lingkungannya sedemikian rupa sehingga kualitas hidup dan kehidupannya menjadi makin baik.

Menurut Undang-Undang Republik Indonesia Nomor 3 Tahun 2005 tentang Sistem Keolahragaan Nasional dan Peraturan Pemerintah Republik Indonesia Nomor 16 Tahun 2007 tentang P enyelenggaraan Keolahragaan, olahraga adalah segala kegiatan yang sistematis untuk mendorong, membina, serta mengembangkan potensi jasmani, rohani, dan sosial. Ruang lingkup olahraga meliputi kegiatan olahraga pendidikan, olahraga rekreasi, dan olahraga prestasi. Olahraga pendidikan adalah pendidikan jasmani dan olahraga yang dilaksanakan 
sebagai bagian proses pendidikan yang teratur dan berkelanjutan untuk memperoleh pengetahuan, kepribadian, keterampilan, kesehatan, dan kebugaran jasmani.

Undang-Undang Republik Indonesia Nomor 3 Pasal 17 Tahun 2005 Tentang Sistem Keolahragaan Nasional Ruang lingkup olahraga meliputi kegiatan: a) olahraga pendidikan; b) olahraga rekreasi; c) olahraga prestasi.

Didunia ada dua jenis olahraga, yaitu olahraga modern dan olahraga tradisional. Olahraga modern adalah olahraga yang telah mengalami perubahan dan peraturan permainan mengikuti perkembangan zaman serta teknologi yang berkembang di dunia. dan olahraga tradisional adalah olahraga asli dari berbagai daerah di indonesia, mungkin belum terkenal di tingkat nasional namun cukup populer di daerah aslinya, seperti permainan bola voli di kalangan masyarakat kecil mereka belum mengenal adanya bola voli pantai.

Voli pantai adalah dari bola voli yang dimainkan di atas pasir. Salah satu olahraga yang menggunakan bola dan dimainkan oleh dua tim berbeda dengan menggunakan lengan atau tangan. Lapangan yang digunakan dalam permainan bola voli pantai memiliki ukuran lebih jika dibandingkan dengan lapangan bola voli indoor yang mana memiliki ukuran 9x9 meter (ukuran setengah lapangan), sedangkan lapangan yang digunakan pada permainan bola voli pantai hanya berukuran 8 x 8 meter. Dalam permainan Bola Voli pantai lebih berat dalam melakukan lompatan dibandingkan dengan bola voli indoor, begitu juga dengan energy yang di butuhkan saat bermain voli pantai lebih besar, dengan jumlah pemain yang lebih sedikit membuat pergerakan lebih berat di pasir dari pada di indoor. Salah satu factor yang baik untuk melakukan smash, blok, spike dibutuhkan kekuatan otot tungkai agat tinggi lompatan dapat maksimal. Salah satu faktor yang berperan dalam pencapain prestasi olahraga adalah faktor fisik terutama kekuatan otot tungkai. Seseorang yang mempunyai kekuatan otot tungkai yang baik dapat melakukan aktifitas dengan baik.

Tinggi lompatan berperan sangat penting dalam permainan bola voli. Semakin tinggi lompatan pemain maka semakin mudah pemain untuk dapat menjangkau bola dalam melakukan smash, serve dan block. Jurnal iptek olahraga yang ditulis oleh (Yonanda, 2021) mengungkapkan bahwa semakin tinggi 
lompatan dianggap semakin besar pula power otot tungkai yang dimiliki seorang atlet atau pemain tersebut.

Namun secara umum Atlet voli pantai mahasiswa Penjas masih memiliki lompatan yang kurang maksimal, maka dari itu peneliti tertarik akan penelitian "Pengaruh Plyometric Training Dalam Bentuk Circuit Training Terhadap Tinggi Lompatan Atlit Bola Voli Pantai Mahasiswa Penjas Universitas Bengkulu”.

\section{METODE}

Jenis penelitian yang digunakan adalah penelitian eksperimen semu. Tujuan penelitian ini yaitu untuk mengetahui Pengaruh Plyometrics Dalam Bentuk Circuit Training Terhadap Tinggi lompatan Mahasiswa Pemain Bola Voli Pantai Prodi Penjas Universitas Bengkulu. Oleh karena itu, dalam penelitian eksperimen semu ini dapat meramalkan variable terikat $(\mathrm{Y})$ dari variable bebas $(\mathrm{X})$. Variable bebasnya adalah plyometric training dalam bentuk Circuit Training, dan variable terikatnya adalah tinggi lompatan mahasiswa pemain bola voli pantai prodi Penjas Universitas Bengkulu.

Sesuai dengan judul penelitian " Pengaruh Plyometric Training Dalam Bentuk Circuit Training Terhadap tinggi lompatan Mahasiswa Pemain Bola Voli Pantai Prodi Penjas Universitas Bengkulu "maka penelitian ini berjenis penelitian eksperimen. Penelitian ini dibagi menjadi 3 tahapan yakni pretest, pemberian perlakuan (treatment), perlakuan yang dilakukan selama 6 minggu, 1 minggu 3 kali pertemuan. Jadi selama 6 minggu dilakukan 18 kali pertemuan. dan post test, Desain yang di gunakan dalam penelitian ini adalah one group pretest-posttest design. Dalam design ini tidak menggunakan kelompok kontrol dan subyek tidak ditempatkan secara acak. Kelebihan dari design ini adalah dilakukanya pretest dan posttest sehingga dapat diketahui pasti perbedaan hasil akibat perlakuan yang diberikan (treatment).

Teknik pengambilan sampel dalam penelitian ini menggunakan teknik purposive sampling. Artinya teknik pengambilan sampel dilakukan secara sengaja sesuai dengan persyaratan sampel yang di tentukan. Berdasarkan teknik sampel di atas maka sampel dalam penelitian ini berjumlah 30 orang 
1. Uji Normalitas

Uji normalitas yang paling sederhana adalah membuat grafik distribusi frekuensi atas skor yang ada. Pada saat sekarang ini sudah banyak cara yang dikembangkan para ahli untuk melakukan pengujian normalitas. Beberapa diantaranya adalah Uji Lilliefors (Usmadi, 2020: 58).

$$
Z i=\frac{X i-\bar{X}}{S}
$$

Keterangan :

$\mathrm{Z}_{\mathrm{i}}=$ Angka Baku

$\mathrm{X}_{\mathrm{i}}=$ Angka Pada Data

$\mathrm{X}=$ Nilai Rata-Rata

$\mathrm{S}=$ Simpangan Baku

Dengan kriteria pengujian sebagai berikut :

Jika $\mathbf{L}_{\text {hitung }}<\mathbf{L}_{\text {tabel }}$ artinya data berdistribusi normal dan jika sebaliknya data tersebut tidak berdistribusi normal.

2. Uji Homogenitas

Uji homogenitas menggunakan uji $\mathbf{F}$ dengan rumus sebagai berikut :

$$
F=\frac{\text { V terbesar }}{V \text { terkecil }}
$$

Dengan kriteria sebagai berikut :

Jika $\mathbf{F}_{\text {hitung }}<\mathbf{F}_{\text {tabel }}$ maka data homogen dan sebaliknya maka data tidak homogen.

3. Pengujian Hipotesis

Uji hipotesis digunakan untuk mengetahui ada atau tidaknya perbandingan dari latihan Multiple Hop Jump (Lompat Gawang) dan naik turun tangga.Untuk menguji hipotesis dalam penelitian ini menggunakan uji t sampel sejenis. Uji $\mathrm{t}$ sampel sejenis dimaksudkan bahwa distribusi data yang dibandingkan berasal dari kelompok subjek yang sama.

$$
t_{\mathrm{o}}=\frac{\mathrm{MD}}{\mathrm{SEMD}}
$$


Pernando Pevriansyah, Tono Sugihartono, Arwin

Pengaruh Plyometric Training dalam bentuk Circuit Training Terhadap Tinggi Lompatan Mahasiswa Pemain Bola Voli Pantai Prodi Penjas Universitas Bengkulu

Dengan kriteria sebagai berikut:

$\mathrm{t}_{\text {hitung }}>\mathrm{t}_{\text {tabel }}$ berarti signifikan

$\mathrm{t}_{\text {hitung }}<\mathrm{t}_{\text {tabel }}$ berarti tidak signifikan

\section{HASIL}

a. Hasil Pretest Tes Tinggi Lompatan

\begin{tabular}{cccc}
\hline No & Kelas Interval & Frekuensi & Kategori \\
\hline $\mathbf{1}$ & $19-25$ & 1 & Kurang Sekali \\
\hline $\mathbf{2}$ & $26-32$ & 0 & Kurang \\
\hline $\mathbf{3}$ & $33-39$ & 5 & Kurang \\
\hline $\mathbf{4}$ & $40-46$ & 2 & Sedang \\
\hline $\mathbf{5}$ & $47-53$ & 10 & Sedang \\
\hline $\mathbf{6}$ & $54-60$ & 9 & Baik \\
\hline $\mathbf{7}$ & $61-67$ & 3 & Sangat Baik \\
\hline & Jumlah & $\mathbf{3 0}$ & \\
\hline
\end{tabular}

b. Hasil Posstest Tes Power Tinggi Lompatan

\begin{tabular}{cccc}
\hline No & Kelas Interval & Frekuensi & Kategori \\
\hline $\mathbf{1}$ & $41-46$ & 1 & Sedang \\
\hline $\mathbf{2}$ & $47-52$ & 4 & Sedang \\
\hline $\mathbf{3}$ & $53-58$ & 5 & Sedang \\
\hline $\mathbf{4}$ & $59-64$ & 10 & Baik \\
\hline $\mathbf{5}$ & $65-70$ & 8 & Sangat Baik \\
\hline $\mathbf{6}$ & $71-76$ & 2 & Sangat Baik \\
\hline & Jumlah & $\mathbf{3 0}$ & \\
\hline
\end{tabular}

c. Deskripsi Statistik Pretest \& Posttest Vertical Jump

\begin{tabular}{ccc}
\hline Statistik & Pretest & Posttest \\
\hline N & 30 & 30 \\
\hline Mean & 49,56 & 60,46 \\
\hline Std. Deviation & 9,92 & 7,63 \\
\hline Minimum & 19 & 41 \\
\hline Maximum & 65 & 76 \\
\hline
\end{tabular}

d. Uji Normalitas 


\begin{tabular}{cccccc}
\hline $\mathbf{N}$ & Tes & Awal & Tes & Akhir & Ket \\
\hline & $\mathrm{L}_{\mathrm{O}}$ & $\mathrm{L}_{\mathrm{T}}$ & $\mathrm{L}_{\mathrm{O}}$ & $\mathrm{L}_{\mathrm{T}}$ & Distribusi \\
\hline $\mathbf{3 0}$ & 0,110 & 0,161 & 0,065 & 0,161 & Normal
\end{tabular}

e. Uji Homogenitas

\begin{tabular}{cccc}
\hline No & Variabel & Standar Deviasi & Varians $\left(\mathbf{S}^{\mathbf{2}}\right.$ \\
\hline $\mathbf{1}$ & Tes Awal & 98,598 & 9,929 \\
\hline $\mathbf{2}$ & Tes Akhir & 58,32 & 7,63
\end{tabular}

f. Uji T Berdasarkan hasil tes awal dan tes akhir vertical jump

\begin{tabular}{ccccc}
\hline No & $\mathbf{N}$ & \multicolumn{2}{c}{ Tes Awal Dan Tes Akhir } & Ket \\
\hline & & t hitung & t tabel & Kesimpulan \\
\hline $\mathbf{1}$ & 30 & 9,00 & 1,697 & Signifikan \\
\hline
\end{tabular}

\section{PEMBAHASAN}

Latihan yang di laksanakan selama 18 kali pertemuan terbukti berhasil memberikan pengaruh terhadap peningkatan power otot tungkai mahasiwa pemain bola voli pantai prodi penjas Universitas Bengkulu. Seperti yang di katakan (Arifianto et al., 2021) latihan adalah aktifitas untuk meningkatkan kualitas fungsi sistem organ tubuh manusia sehingga mempermudah atlet dalam penyempurnaan geraknya dan latihan adalah proses dimana seseorang atlet dipersiapkan untuk peforma tertinggi

Latihan plyometric adalah kunci pengembangan kekuatan atletik yang relevan dengan mayoritas olahraga (Ilham et al., 2021) dan plyometric adalah pelatihan teknik yang digunakan oleh atlet semua jenis olahraga untuk meningkatkan kekuatan dan daya ledak (Asadi et al., 2018) Tidak hanya itu, masih ada banyak faktor lain yang bisa mempengaruhi peningkatan power otot tungkai. Gizi adalah satu hal penting dalam peroses peningkatan power otot tungkai, seperti yang dikatakan (Sovensi, 2018) zat gizi sangat di perlukan oleh tubuh karena mempunyai manfaat yang besar terhadap pertumbuhan dan 
perkembangan manusia, dan kebutuhan gizi harus dicukupi secara baik karena terjadinya proses pertumbuhan yang cepat dalam aktifitas yang tinggi.

Kelebihan dari latihan ini adalah ketika atlet loncat di pasir ketika atlet ingin menolak atau meloncat maka kaki atlet tersebut masuk kedalam pasir, sehingga menjadi beban ketika atlet meloncat. dan ketika atlet loncat di tempat yang datar maka tinggi loncatan alet tersebut akan bertambah. Dalam memberikan program latihan plyometric di pasir peneliti memberikan latihan dengan berbagai macam variasi, yang bertujuan siswi dapat berlatih dengan gembira dan tidak mengalami kejenuhan ketika latihan serta membuat latihan menjadi tidak monoton.

Teori-teori di atas memperkuat bahwa latihan plyometric di pasir berpengaruh terhadap peningkatan power otot tungkai mahasiswa pemain bola voli pantai prodi penjas Universitas Bengkulu. Peningkatan power otot tungkai terlihat pada perbandingan perubahan rata-rata pretest dan posttest. Hasil rata-rata pretest sebesar 49,566 dan hasil rata rata posttest sebesar 60,466 dengan selisih 10,9. Dari hasil penelitian menunjukkan bahwa selisih mean antara pretest dan posttest mahasiswa setelah mengikuti program latihan plyometric di pasir sebanyak 18 kali pertemuan dapat menunjukkan peningkatan terhadap power otot tungkai mahasiswa. Hasil rata-rata tersebut dengan waktu latihan yang relatif pendek hanya dapat menyebabkan perubahan akibat latihan yang bersifat sementara dan akan mudah sekali kembali pada keadaan semula. Namun, waktu latihan yang relatif lama akan menyebabkan terjadinya perubahan akibat latihan yang bersifat tetap dan tidak bersifat sementara.

Dari hasil t hitung sebesar 9,00 lebih $>$ dari t tabel 1,697. Maka ada pengaruh latihan plyometrics training terhadap power otot tungkai secara signifikan. Dengan demikian hipotesis yang berbunyi "Ada pengaruh latihan plyometric di pasir terhadap power otot tungkai mahasiwa pemain bola voli pantai Universitas Bengkulu" diterima secara signifikan. Mengingat pentingnya kekuatan power pada otot tungkai dalam aktifitas fisik maka perlu sekali upaya untuk meningkatkan kekuatan pada power otot tungkai mahasiswa pemain bola voli pantai prodi penjas Universitas Bengkulu. Power otot tungkai siswi dapat 
meningkat apabila latihan dilakukan secara terprogram, terencana, dan dilakukan dengan benar.

Dengan demikian dapat di simpulkan bahwapenelitian yang telah dilakukan dengan pemberian latihan plyometric di pasir terbukti dapat meningkatkan power otot tungkai mahasiswa pemain bola voli prodi penjas Universitas Bengkulu.

\section{KESIMPULAN}

Berdasarkan hasil penelitian dan pembahasan yang telah dikemukakan di atas maka dapat disimpulkan bahwa, ada pengaruh latihan plyometric training dalam bentuk circuit training terhadap tinggi lompatan mahasiswa pemain bola voli pantai Prodi Penjas Universitas Bengkulu yang ditunjukkan dengan hasil uji-t pada $a=0,05$, $t$ hitung di peroleh sebesar 9,00 dan $\mathrm{t}$ tabel sebesar 1,69 ternyata bahwa thitung $>$ dari $\mathrm{t}$ tabel maka dengan demikian hipotesis yang berbunyi "Ada pengaruh latihan plyometric training terhadap tinggi lompatan dapat diterima secara signifikan pada $a=0,05 "$.

\section{REFERENSI}

Arifianto, I., Raibowo, S., \& Jatra, R. (2021). Groundstroke Training Games Dalam Bentuk Video untuk Atlet Junior Tenis Lapangan. Jurnal Menssana, 6(1), 12-22. https://doi.org/10.24036/MensSana.06012021.18

Asadi, A., Ramirez-Campillo, R., Arazi, H., \& Sáez de Villarreal, E. (2018). The effects of maturation on jumping ability and sprint adaptations to plyometric training in youth soccer players. Journal of Sports Sciences, 36(21), 24052411. https://doi.org/10.1080/02640414.2018.1459151

Ilham, T. R., Pujianto, D., \& Arwin. (2021). Pengaruh Latihan Plyometrics ( Hurdle Hops dan Ladder Drill ) Terhadap Kecepatan Dribbling Futsal Putri Tim Jugador Bonita Rafflesia. Sport Gymnastics: Jurnal Ilmiah Pendidikan Jasmani, 2(1), 34-45. https://doi.org/10.33369/gymnastics

Sovensi, E. (2018). Efek Latihan "Power Plyometrics" Dalam Sistem Set dan Sistem Sirkuit Terhadap Peningkatan Daya Ledak Otot Tungkai. Jurnal Stamina, 1(1), 5-24. https://doi.org/10.24036/jst.v1i1.6

USMADI. (2020). PENGUJIAN PERSYARATAN ANALISIS. INOVASI PENDIDIKAN, 7(1), 58.

Yonanda, A. (2021). Pengaruh Latihan Plyometric dalam bentuk circuit raining terhadap tinggi lompatan bola voli pasir. 